\section{Methods to Improve the Rooting of Hardwood Cuttings of the 'Gisela 5' Cherry Rootstock}

\author{
Efstathia Exadaktylou ${ }^{1}$, Thomas Thomidis ${ }^{2,5}$, Brian Grout $^{3}$, \\ George Zakynthinos ${ }^{4}$, and Constantinos Tsipouridis ${ }^{1}$
}

AdDitional Index wORDs. Agrobacterium rubi, indole-3-butyric acid, IBA, seasonal timing collection, cutting size, substrate

Summary. The effect of external factors on the rooting of hardwood cuttings of the 'Gisela 5' cherry rootstock (Prunus cerasus $\times$ Prunus canescens) was studied. Experiments were conducted with cuttings of different lengths $(15,20,25$, and 30 $\mathrm{cm}$ ) and diameters ( 6 to 8,9 to 11 , and 12 to $14 \mathrm{~mm}$ ) and with different indole- 3 butyric acid (IBA) concentrations $\left(0,1,2,3,4\right.$, and $\left.6 \mathrm{~g} \cdot \mathrm{L}^{-1}\right)$. Significantly improved rooting was achieved using cuttings $20 \mathrm{~cm}$ long and 9 to $11 \mathrm{~mm}$ in diameter collected in November or March from the upper part of the parent shoot and subsequently quick-dipped in $1 \mathrm{~g} \cdot \mathrm{L}^{-1} \mathrm{IBA}$ solution. Cuttings placed vertically in perlite:peat $(1: 1)$ or perlite with bottom heat gave the best rooting percentage. No effect on callusing or rooting of cuttings was found after incubation of cutting in suspensions of Agrobacterium rubi. If the optimal combination of factors is selected, 'Gisela 5' can be propagated from hardwood cuttings with a rooting efficiency of $\approx \mathbf{5 0 \%}$.

G isela $5^{\prime}$ is a triploid hybrid developed at the University of Giessen, Germany, and is among the best dwarfing $[\approx 50 \%$ of 'Mazzard' sweet cherry (Prunus avium)], precocious and productive rootstocks for modern, intensive sweet cherry growing (Bassi, 2005; Liu et al., 2005; Sitarek et al., 2005; Walter and Franken, 1998; Whiting and Ophardt, 2005; Yang et al., 2005; Zimmermann, 1994). It has good grafting compatibility, tolerance to ilarviruses, and adaptation to various edaphoclimate conditions (Lugli et al., 2005; Walter and Franken, 1998). This rootstock has shown very good adaptability in Greek soil-climate conditions and has replaced 'Mazzard' rootstocks in many cherry orchards.

Hardwood cuttings are most often used in propagation of deciduous woody plants (Hartmann et al., 2002) as one of the cheapest and easiest methods of vegetative propagation. They are easily handled, are not readily perishable, and may be shipped safely over long distances.

${ }^{1}$ NAGREF, Pomology Institute, R. S. Naoussa 38, Naoussia, Imathia 59200, Greece

${ }^{2}$ Technological Education Institute of Thessaloniki, P.C. 57400, Macedonia, Greece

${ }^{3}$ University of Copenhagen, Faculty of Life Science, Hoejbakkegaard Alle 212630, Taastrup, Denmark

${ }^{4}$ Technological Educational Institute of Kalamata, Antikalamos 24100, Greece

${ }^{5}$ Corresponding author. E-mail: thomi-1@otenet.gr.
Typically, they require little or no special equipment during rooting, which can be readily performed in commercial nurseries. Previous work has demonstrated the propagation of 'Gisela 5' cherry rootstock from leaf, greenwood, and soft cuttings (Stefancic et al., 2006; Trobec et al., 2004), but no data are available for the propagation of this rootstock by hardwood cuttings.

Many external factors such as cutting length and diameter, applied indole-3-butyric acid (IBA) concentration, date of cutting collection, and preheating can affect and increase rooting of hardwood cuttings of many species (Gill and Chitkara, 1990; Loach, 1988; Tofanelli et al., 2003) by influencing the endogenous auxin and carbohydrate contents of the tissues (Hartmann et al., 2002). Some bacteria such as those belonging to the genus Agrobacterium release auxin, can also have a positive effect on the rooting of cuttings (Sezai et al., 2003a, 2003b). Furthermore, a correlation among polarity, root differentiation, and auxin movement can be made (Hartmann et al., 2002).

This study investigated the effect of several external factors (cutting length, thickness, IBA concentration, orientation, rooting substrate, position of cutting on the shoot, and application of Agrobacterium rubi) in an attempt to improve the rooting of hardwood cuttings of the 'Gisela 5' cherry rootstock for use in the Greek horticultural industry.

\section{Materials and methods}

Plant material. Mother trees (1-year-old) were established at the Pomology Institute (NAGREF), Naoussa, Greece, where the climate is temperate. As part of standard maintenance, irrigation was provided five to six times in a vegetative season, Bordeaux mixture was sprayed at the leaf fall stage, and nitrogen (ammonium sulphate at $120 \mathrm{~kg} \cdot \mathrm{ha}^{-1} \mathrm{~N}$ ) was applied each year in the middle of February. The mother trees were $\approx 1.5 \mathrm{~m}$ high when the cuttings were collected.

Cuttings were taken from the previous season's growth, 60 to 80 $\mathrm{cm}$ in two consecutive years $(2003$ and 2004), and percentage rooting and percentage callusing (includes cuttings with callus and those with callus plus roots) were recorded 2 months after treatment. Cuttings were inserted to a depth of $10 \mathrm{~cm}$ in rooting substrate with bottom heat. The rooting substrate was 3:1 river sand (total porosity $35 \%$, waterholding capacity 25\%) and perlite (total porosity $75 \%$, waterholding capacity 20\%; Argyrometalevmaton and Varytins, Mylos, Greece). The temperature at the base of cuttings was maintained at $18 \pm 2{ }^{\circ} \mathrm{C}$. Cuttings were held in a glass house $(10 \times 12 \times 4 \mathrm{~m})$ with natural light $(\approx 11$ h per day) and a relative humidity that fluctuated between $70 \%$ and $90 \%$. Cuttings were irrigated once per week.

Preparation of indole-3BUTYRIC ACID SOLUTIONS. Indole-3butyric acid was first dissolved in $3 \mathrm{~mL}$

\begin{tabular}{llll}
\hline $\begin{array}{l}\text { Units } \\
\text { To convert U.S. to SI, } \\
\text { multiply by }\end{array}$ & U.S. unit & SI unit & $\begin{array}{l}\text { To convert SI to U.S., } \\
\text { multiply by }\end{array}$ \\
\hline 29.5735 & $\mathrm{fl} \mathrm{oz}$ & $\mathrm{mL}$ & 0.0338 \\
0.3048 & $\mathrm{ft}$ & $\mathrm{m}$ & 3.2808 \\
2.54 & inch $(\mathrm{es})$ & $\mathrm{cm}$ & 0.3937 \\
25.4 & inch $(\mathrm{es})$ & $\mathrm{mm}$ & 0.0394 \\
1.1209 & lb/acre & $\mathrm{kg} \cdot \mathrm{ha}^{-1}$ & 0.8922 \\
0.001 & $\mathrm{ppm}$ & $\mathrm{g} \cdot \mathrm{L}^{-1}$ & 1000 \\
$\left({ }^{\circ} \mathrm{F}-32\right) \div 1.8$ & ${ }^{\circ} \mathrm{F}$ & ${ }^{\circ} \mathrm{C}$ & $\left(1.8 \times{ }^{\circ} \mathrm{C}\right)+32$
\end{tabular}


absolute ethanol and subsequently diluted to a concentration of $50 \% \mathrm{v} /$ $\mathrm{v}$ ethanol, which was subsequently increased to $500 \mathrm{~mL}$ (by adding absolute ethanol) with simultaneous stirring, and then another $500 \mathrm{~mL}$ of distilled water was added. The control solution was $50 \% \mathrm{v} / \mathrm{v}$ ethanol.

AGRobaCtERIUM RUBI TREATMENTs. Two isolates of $A$. rubi (B63 and B149; LMG Bacterial Collection, Laboratorium voor Microbiologie Universiteit Gent, Gent, Belgium) were used and grown for $5 \mathrm{~d}$ on nutrient agar with beef extract $(0.3 \%$ $\mathrm{w} / \mathrm{v})$, peptone $(0.5 \% \mathrm{w} / \mathrm{v})$, and agar $(1.5 \% \mathrm{w} / \mathrm{v})$. When required, the bacterial growth was scraped aseptically from the plate surface with a loop and suspended in sterile distilled water. The concentrations of the suspensions are provided in Table 1. $\mathrm{cm}$ in diameter) were collected on 30 Nov. and first dipped to $1 \mathrm{~cm}$ in the IBA solution $\left(1 \mathrm{~g} \cdot \mathrm{L}^{-1}\right)$ for $15 \mathrm{~s}$ and left to dry at room temperature for $l \mathrm{~h}$. This avoids problems that result from exposing the bacterial cells to the relatively high alcohol concentration. The choice of IBA level was based on an unpublished study in which rooting of peach (Prunus persica) rootstock cuttings was improved by $A$. rhizogenes treatment. Subsequently, the cutting bases were dipped in the A. rubi suspension for $30 \mathrm{~min}$ (Table 1). Cuttings were set in the $3: 1$ sand:perlite rooting substrate with bottom heat as described previously.

The experiment was designed as a completely randomized block with
Cuttings $(20 \mathrm{~cm}$ long, 1.2 to 1.4

two bacteria strains $\times$ two IBA concentrations $\times$ five replicates of 20 cuttings.

Cutting length. Cuttings of 9 to $11 \mathrm{~mm}$ diameter were taken on 30 Nov., trimmed to a length of 15,20 , 25 , or $30 \mathrm{~cm}$, and dipped to $1 \mathrm{~cm}$ in a $\mathrm{l} g \cdot \mathrm{L}^{-1} \mathrm{IBA}$ solution for $15 \mathrm{~s}$. After surface drying, the bases were treated with a powder containing $50 \% \mathrm{w} / \mathrm{v}$ talcum powder and $50 \% \mathrm{w} / \mathrm{v}$ captan (Captan 75W; Euthimiadis, Sindos, Greece) as a protective fungicide against a variety of soil pathogens. Cuttings were set in the 3:1 sand:perlite rooting substrate with bottom heat as described previously.

The experiment was designed as a completely randomized block with four cutting lengths $\times$ five replicates of 20 cuttings.

INDOLE-3-BUTYRIC ACID CONCEN TRATION AND CUTTING BASE DIAMETER. Cuttings were taken on 30 Nov. and trimmed to $20 \mathrm{~cm}$ in length with diameters of 6 to 8,9 to 11 , or 12 to $14 \mathrm{~mm}$ measured at the base of each cutting. These were dipped to 1 $\mathrm{cm}$ for $15 \mathrm{~s}$ in IBA solutions $(1,2,3$, or $\left.6 \mathrm{~g} \cdot \mathrm{L}^{-1}\right)$. Cuttings were set in the $3: 1$ sand:perlite rooting substrate with bottom heat as described previously.

The experiment was designed as a completely randomized block with three diameters $\times$ six IBA levels $\times$ five replicates of 20 cuttings.

CUtTING POSITION WITHIN THE PARENT SHOOT AND COLLECTION DATE. Cuttings of $20 \mathrm{~cm}$ length and 9 to $11 \mathrm{~mm}$ in diameter were taken on 15 Nov., 5 Dec., and 1

Table 1. Effect of the bacterium Agrobacterium rubi on percentage of callusing (cuttings with callus + cuttings with roots) and rooting of the 'Gisela 5' cherry rootstock hardwood cuttings $20 \mathrm{~cm}$ ( 7.9 inches) long and 12 to $14 \mathrm{~mm}(0.47$ to 0.55 inch) in diameter.

\begin{tabular}{|c|c|c|c|c|c|c|}
\hline \multirow[b]{2}{*}{ Treatment } & \multirow{2}{*}{$\begin{array}{l}\text { A. rubi cells } \\
(10,000 / \mathrm{mL})^{\mathrm{z}}\end{array}$} & \multirow{2}{*}{$\begin{array}{l}\text { IBA concn } \\
\left(\mathrm{g} \cdot \mathrm{L}^{-1}\right)^{\mathrm{y}}\end{array}$} & \multirow{2}{*}{$\frac{\text { Callusing (\%) }}{\text { Mean }}$} & \multicolumn{3}{|c|}{ Rooting (\%) } \\
\hline & & & & Year 1 & Year 2 & Mean \\
\hline Control & - & - & $92 \mathrm{a}^{\mathrm{w}}$ & $8 \mathrm{a}$ & $11 \mathrm{a}$ & $10 \mathrm{a}$ \\
\hline$B 149^{x}$ & 712 & - & $96 \mathrm{a}$ & $0 \mathrm{~b}$ & $0 \mathrm{~b}$ & $0 \mathrm{~b}$ \\
\hline B149 & 8,860 & - & $90 \mathrm{a}$ & $0 \mathrm{~b}$ & $0 \mathrm{~b}$ & $0 \mathrm{~b}$ \\
\hline $\mathrm{B} 149+\mathrm{IBA}$ & 712 & 1 & $72 \mathrm{c}$ & $0 \mathrm{~b}$ & $0 \mathrm{~b}$ & $0 \mathrm{~b}$ \\
\hline $\mathrm{B} 149+\mathrm{IBA}$ & 8,860 & 1 & $80 \mathrm{bc}$ & $0 \mathrm{~b}$ & $0 \mathrm{~b}$ & $0 \mathrm{~b}$ \\
\hline$B 63^{x}$ & 915 & - & $92 \mathrm{a}$ & $0 \mathrm{~b}$ & $0 \mathrm{~b}$ & $0 \mathrm{~b}$ \\
\hline B63 & 7,900 & - & $88 \mathrm{ab}$ & $6 \mathrm{a}$ & $10 \mathrm{a}$ & $8 \mathrm{a}$ \\
\hline $\mathrm{IBA}+\mathrm{B} 63$ & 915 & 1 & $76 \mathrm{c}$ & $0 \mathrm{~b}$ & $0 \mathrm{~b}$ & $0 \mathrm{~b}$ \\
\hline $\mathrm{IBA}+\mathrm{B} 63$ & 7,900 & 1 & $72 \mathrm{c}$ & $0 \mathrm{~b}$ & $0 \mathrm{~b}$ & $0 \mathrm{~b}$ \\
\hline
\end{tabular}

${ }^{2} 1 \mathrm{cell} / \mathrm{mL}=29.5735$ cells $/ \mathrm{fl} \mathrm{oz}$.

IBA = indole-3-butyric acid; $1 \mathrm{~g} \cdot \mathrm{L}^{-1}=1000 \mathrm{ppm}$.

${ }^{\times} \mathrm{B} 149$ and $\mathrm{B} 63=$ strains of $A$. rubi.

"Means are calculated from five replicates of 20 cuttings each. Values in the same column followed by different letters are significantly different $(P<0.05)$ according to Wald test.
Mar. from different positions on the parent shoot (upper, middle, and lower). The choice of dates was based on a previous study (C. Tsipouridis, unpublished data). Cuttings were treated with $1 \mathrm{~g} \cdot \mathrm{L}^{-1} \mathrm{IBA}$ and set in the 3:1 sand:perlite rooting substrate with bottom heat as described previously.

The experiment was designed as a completely randomized block with three collecting dates $\times$ three positions $\times$ five replicates of 20 cuttings.

Different substrates. Cuttings of $20 \mathrm{~cm}$ length and 9 to 11 $\mathrm{mm}$ diameter were taken on 30 Nov. and treated with $1 \mathrm{~g} \cdot \mathrm{L}^{-1} \mathrm{IBA}$ as described previously. Six different rooting substrates were used: peat, perlite, peat and perlite 1:1, sand, coarse vermiculite, and fine vermiculite. The sand and perlite were described previously. The peat (Klasmann-Deilmann, Geeste, Germany) had a total porosity of $70 \%$ and a waterholding capacity of $35 \%$. Peat and perlite $1: 1$ had a total porosity of $70 \%$ and a waterholding capacity of $30 \%$. Fine vermiculite (total porosity $50 \%$, waterholding capacity 55\%) and coarse vermiculite (total porosity 60\%, waterholding capacity $40 \%$ ) were supplied by Mathios Pefractories (Athens, Greece). Cuttings were treated and set in the appropriate rooting substrate with bottom heat as described previously.

The experiment was designed as a completely randomized block with six rooting substrates $\times$ five replicates of 20 cuttings.

Cutting orientation. The correlation of polarity of root differentiation with auxin movement is known and also the polarity in auxin varies in intensity among different tissues (Hartmann et al., 2002). These experiments were conducted to confirm that the orientation affects the rooting of the 'Gisela 5' cherry rootstock hardwood cuttings.

Cuttings of $20 \mathrm{~cm}$ long and 9 to $11 \mathrm{~mm}$ diameter were collected on 5 Dec., stored at 0 to $3{ }^{\circ} \mathrm{C}$ for $17 \mathrm{~d}$, and then prepared and treated with IBA as described previously. The cuttings were set vertically in the conventional orientation, horizontally, inverted, and at $45^{\circ}$ in the sand:perlite rooting substrate with bottom heat as described previously.

The experiment was designed as a completely randomized block with four cutting orientations $\times$ five replicates of 20 cuttings. 
Statistical ANALYsis. In all experiments, years and blocks were taken as random effect factors and treatments as fixed effect factors. To test significant differences between treatments and interactions, the Generalized Linear Models (SPSS Grad Pack 16 for Windows; SPSS, Chicago, IL) were applied at $P=0.05$.

In all experiments, statistical analyses of the data were carried out after angular transformation. Significant differences between treatments were tested by Wald test at $P=0.05$.

\section{Results}

AgrobaCteriUM RUBI TREATMENTS. Agrobacterium rubi did not improve the callusing or rooting performance of the 'Gisela 5' cherry rootstocks (Table 1 ) and in some treatments, the percentage of callusing and rooting was reduced significantly below control levels.

Cutting Length. The highest rooting percentage was found on 20 $\mathrm{cm}$ cuttings and the lowest on those $30 \mathrm{~cm}$ in length (Table 2). Cuttings of $25 \mathrm{~cm}$ exhibited a higher rooting percentage than those of 15 and 30 $\mathrm{cm}$ in both years. In both years, 15 $\mathrm{cm}$ cuttings did not show a significant difference in rooting from those of 30 $\mathrm{cm}$.

INDOLE-3-BUTYRIC ACID CONCEN TRATION AND CUTTING BASE DIAMETER. Cuttings without IBA treatment and those dipped in $2 \mathrm{~g} \cdot \mathrm{L}^{-1}$ IBA had a relatively high callusing percentage, but significantly less than those dipped in $1 \mathrm{~g} \cdot \mathrm{L}^{-1}$ IBA (Table 3 ). As IBA concentration increased, the callusing percentage was reduced. Cuttings with a 6 to $8 \mathrm{~mm}$ diameter and treated

Table 2. The effect of cutting length on rooting percentage of hardwood cuttings of the 'Gisela 5' cherry rootstock hardwood cuttings 9 to $11 \mathrm{~mm}(0.35$ to 0.43 inch $)$ in diameter.

\begin{tabular}{llcc}
\hline $\begin{array}{l}\text { Cutting } \\
\text { length } \\
(\mathrm{cm})^{\mathrm{z}}\end{array}$ & \begin{tabular}{l} 
Rooting (\%) \\
\cline { 2 - 4 }
\end{tabular} & $\begin{array}{l}\text { Fearst } \\
\text { yecond } \\
\text { year }\end{array}$ & Mean \\
\hline 15 & $13 \mathrm{c}^{\mathrm{y}}$ & $14 \mathrm{c}$ & $14 \mathrm{c}$ \\
20 & $44 \mathrm{a}$ & $42 \mathrm{a}$ & $43 \mathrm{a}$ \\
25 & $33 \mathrm{~b}$ & $31 \mathrm{~b}$ & $32 \mathrm{~b}$ \\
30 & $6 \mathrm{c}$ & $17 \mathrm{c}$ & $12 \mathrm{c}$ \\
\hline
\end{tabular}

${ }^{\mathrm{z}} 1 \mathrm{~cm}=0.3937$ inch.

${ }^{y}$ Means are calculated from five replicates of 20 cuttings each. Values in the same column followed by different letters are significantly different $(P<0.05)$ according to Wald test. with $1 \mathrm{~g} \cdot \mathrm{L}^{-1}$ IBA solution showed the highest callusing percentage. A significant difference in callusing percentage was found between cuttings with 9- to $11-\mathrm{mm}$ and 12 - to $14-\mathrm{mm}$ diameters. Interactions between thickness and IBA concentration for callusing were significant.

Cuttings dipped in $1 \mathrm{~g} \cdot \mathrm{L}^{-1} \mathrm{IBA}$ solution showed the highest percentage of rooting (Table 3 ) and a relatively high rooting percentage was also found on cuttings with $2 \mathrm{~g} \cdot \mathrm{L}^{-1}$ or without IBA treatment. IBA at $3 \mathrm{~g} \cdot \mathrm{L}^{-1}$ significantly reduced the rooting of cuttings and no rooting was seen on cuttings dipped in 4 or $6 \mathrm{~g} \cdot \mathrm{L}^{-1}$ IBA. Cuttings with diameters of 6 to $8 \mathrm{~mm}$ and 9 to $11 \mathrm{~mm}$ showed the highest rooting percentage, whereas no rooting was observed from those with 12 - to $14-\mathrm{mm}$ diameter. Interactions between diameter and IBA concentration for rooting were significant (Table 3 ).

CutTING POSITION WITHIN THE PARENT SHOOT AND COLLECTION DATE. Cuttings taken from the middle or upper part of shoots had higher callusing percentages compared with those taken from the lower part (Table 4 ). Higher callusing was observed on

Table 3. The effect of indole-3-butyric acid (IBA) concentration and cutting diameter on callusing (cuttings with callus and cuttings with roots) and rooting of hardwood cuttings of the 'Gisela 5' cherry rootstock $20 \mathrm{~cm}$ ( 7.9 inches) long.

\begin{tabular}{|c|c|c|c|c|c|c|}
\hline \multirow{3}{*}{$\begin{array}{l}\text { IBA concn } \\
\left(\mathrm{g} \cdot \mathrm{L}^{-1}\right)^{\mathrm{z}}\end{array}$} & \multicolumn{6}{|c|}{ Callusing (\%) } \\
\hline & \multicolumn{3}{|c|}{$\operatorname{Diam}(\mathrm{mm})^{\mathrm{z}}$} & \multirow{2}{*}{$\begin{array}{l}\text { Mean of three } \\
\text { diameters (\%) }\end{array}$} & \multirow[b]{2}{*}{ Year 1} & \multirow[b]{2}{*}{ Year 2} \\
\hline & 6 to 8 & 9 to 11 & 12 to 14 & & & \\
\hline 0 & $71 b^{y}$ & $31 \mathrm{~d}$ & $0 \mathrm{~g}$ & $34 \mathrm{~b}$ & $36 \mathrm{~b}$ & $32 \mathrm{~b}$ \\
\hline 1 & $86 a$ & $70 \mathrm{~b}$ & $21 \mathrm{e}$ & $59 \mathrm{a}$ & $61 \mathrm{a}$ & 56 a \\
\hline 2 & $58 \mathrm{c}$ & $35 \mathrm{~d}$ & $6 \mathrm{f}$ & $33 \mathrm{~b}$ & $35 \mathrm{~b}$ & $29 c$ \\
\hline 3 & $26 \mathrm{de}$ & $12 \mathrm{f}$ & $9 \mathrm{f}$ & $16 \mathrm{c}$ & $18 \mathrm{c}$ & $12 \mathrm{~d}$ \\
\hline 4 & $11 \mathrm{f}$ & $8 \mathrm{f}$ & $0 \mathrm{~g}$ & $6 \mathrm{~d}$ & $6 \mathrm{~d}$ & $6 \mathrm{e}$ \\
\hline 6 & $4 \mathrm{fg}$ & $0 \mathrm{~g}$ & $0 \mathrm{~g}$ & $1 \mathrm{e}$ & $1 \mathrm{e}$ & $1 \mathrm{f}$ \\
\hline \multirow{3}{*}{$\begin{array}{l}\text { Mean IBA } \\
\text { concn }(\%) \\
\end{array}$} & & & & & & \\
\hline & $43 \mathrm{a}$ & $26 \mathrm{~b}$ & $6 \mathrm{c}$ & & & \\
\hline & \multicolumn{6}{|c|}{ Rooting (\%) } \\
\hline \multirow{2}{*}{$\begin{array}{l}\text { IBA concn } \\
\left(\mathrm{g} \cdot \mathrm{L}^{-1}\right)\end{array}$} & \multicolumn{3}{|c|}{$\operatorname{Diam}(\mathrm{mm})$} & \multirow{2}{*}{$\begin{array}{l}\text { Mean of three } \\
\text { diameters (\%) }\end{array}$} & \multirow[b]{2}{*}{ Year 1} & \multirow[b]{2}{*}{ Year 2} \\
\hline & 6 to 8 & 9 to 11 & 12 to 14 & & & \\
\hline 0 & $26 \mathrm{~b}$ & $9 \mathrm{c}$ & $0 \mathrm{~d}$ & $12 \mathrm{c}$ & $13 \mathrm{c}$ & $10 \mathrm{c}$ \\
\hline 1 & $29 \mathrm{~b}$ & 52 a & $0 \mathrm{~d}$ & $27 \mathrm{a}$ & $28 \mathrm{a}$ & $25 \mathrm{a}$ \\
\hline 2 & $24 \mathrm{~b}$ & $25 \mathrm{~b}$ & $0 \mathrm{~d}$ & $16 \mathrm{~b}$ & $18 \mathrm{~b}$ & $14 \mathrm{~b}$ \\
\hline 3 & $8 \mathrm{c}$ & $0 \mathrm{~d}$ & $0 \mathrm{~d}$ & $2 \mathrm{~d}$ & $4 \mathrm{~d}$ & $1 \mathrm{~d}$ \\
\hline 4 & $0 \mathrm{~d}$ & $0 \mathrm{~d}$ & $0 \mathrm{~d}$ & $0 \mathrm{~d}$ & $0 \mathrm{e}$ & $0 \mathrm{~d}$ \\
\hline 6 & $0 \mathrm{~d}$ & $0 \mathrm{~d}$ & $0 \mathrm{~d}$ & $0 \mathrm{~d}$ & $0 \mathrm{e}$ & $0 \mathrm{~d}$ \\
\hline $\begin{array}{l}\text { Mean IBA } \\
\text { concn }(\%)\end{array}$ & $15 \mathrm{a}$ & $14 \mathrm{a}$ & $0 \mathrm{~b}$ & & & \\
\hline
\end{tabular}

${ }^{\mathrm{z}} \mathrm{l} \mathrm{g} \cdot \mathrm{L}^{-1}=1000 \mathrm{ppm} ; 1 \mathrm{~mm}=0.0394$ inch.

${ }^{y}$ Means are calculated from five replicates of 20 cuttings each. Values followed by different letters are significantly different $(P<0.05)$ according to Wald test.

the cuttings taken on 15 Nov. or 2 Mar. than those taken on 1 Dec. Cuttings collected on 15 Nov. and 2 Mar. had similar callusing percentages (Table 4) independent from their position on the parent shoot. No significant difference in callusing was found between cuttings taken from the middle and upper shoot regions collected on 1 Dec., whereas no callusing was found on cuttings taken from the base of the parent shoots. Interactions between cutting position and time of setting for callusing were significant (Table 4 ).

A higher percentage of rooting was found for cuttings collected from the middle or the upper shoot parts in comparison with those taken from the lower region. Cuttings taken on 15 Nov. or 2 Mar. showed higher rooting than those taken on $1 \mathrm{Dec}$. Interactions between cutting position and time of setting for rooting were significant (Table 4). The highest rooting percentage was found on cuttings taken from the base or the upper region of shoots on 15 Nov. or 2 Mar. and cuttings taken on 1 Dec. from the middle of shoots. Cuttings taken from the base of parent shoots showed no rooting. 
Table 4. Effect of cutting position within the parent shoot and collection date on the percentage of callusing (cuttings with callus + cuttings also with roots), and rooting of hardwood cuttings of the 'Gisela 5' cherry rootstock [ $20 \mathrm{~cm}(7.9$ inches) long and 9 to $11 \mathrm{~mm}(0.35$ to 0.43 inch $)$ in diameter].

\begin{tabular}{|c|c|c|c|c|}
\hline \multirow{2}{*}{$\begin{array}{l}\text { Position within } \\
\text { the parent shoot }\end{array}$} & \multicolumn{3}{|c|}{ Callusing (\%) } & \multirow{2}{*}{$\begin{array}{c}\text { Mean of three } \\
\text { dates (\%) }\end{array}$} \\
\hline & 15 Nov. & 1 Dec. & 2 Mar. & \\
\hline Base & $79 a^{z}$ & $0 \mathrm{~d}$ & $75 \mathrm{a}$ & $51 \mathrm{~b}$ \\
\hline Middle & $68 \mathrm{a}$ & $43 \mathrm{c}$ & $75 \mathrm{a}$ & $62 \mathrm{a}$ \\
\hline Top & $78 \mathrm{a}$ & $40 \mathrm{c}$ & $73 \mathrm{a}$ & $64 a$ \\
\hline \multicolumn{5}{|l|}{ Mean of three } \\
\hline positions (\%) & $75 \mathrm{a}$ & $28 \mathrm{~b}$ & $74 \mathrm{a}$ & \\
\hline \multirow{2}{*}{$\begin{array}{l}\text { Position within } \\
\text { the parent shoot }\end{array}$} & \multicolumn{3}{|c|}{ Rooting (\%) } & \multirow{2}{*}{$\begin{array}{c}\text { Mean of three } \\
\text { dates (\%) }\end{array}$} \\
\hline & 15 Nov. & 1 Dec. & 2 Mar. & \\
\hline Base & $35 \mathrm{a}$ & $0 \mathrm{c}$ & $33 \mathrm{a}$ & $23 \mathrm{~b}$ \\
\hline Middle & $29 \mathrm{~b}$ & $33 a$ & $30 \mathrm{~b}$ & $31 \mathrm{a}$ \\
\hline Top & $31 \mathrm{ab}$ & $27 \mathrm{~b}$ & $35 a$ & $31 \mathrm{a}$ \\
\hline $\begin{array}{l}\text { Mean of three } \\
\text { positions (\%) }\end{array}$ & $32 \mathrm{a}$ & $20 \mathrm{~b}$ & $33 a$ & \\
\hline
\end{tabular}

${ }^{2}$ Means are calculated from five replicates of 20 cuttings each. Values followed by different letters are significantly different $(P<0.05)$ according to Wald test.

DiFFERENT SUbSTRATES. Cuttings placed in sand had the highest percentage of callusing with the lowest on cuttings placed into perlite, peat:perlite (1:1), and vermiculite (fine) (Table 5). The callusing percentage of cuttings placed into peat, perlite, peat:perlite (1:1), and vermiculite (fine) were statistically similar with no significant difference in the percentage of callusing between perlite and vermiculite (coarse).

The cuttings in peat:perlite ( $1: 1)$ and perlite gave the highest rooting with no significant difference found

Table 5. Effect of different rooting substrates on percentage of callusing (cuttings with callus + cuttings also with roots) and rooting of the 'Gisela 5' cherry rootstock hardwood cuttings $20 \mathrm{~cm}(7.9$ inches) long and 9 to $11 \mathrm{~mm}(0.35$ to $0.43 \mathrm{inch}$ ) in diameter.

\begin{tabular}{lcc}
\hline $\begin{array}{l}\text { Rooting } \\
\text { substrates }\end{array}$ & $\begin{array}{c}\text { Callusing } \\
(\%)\end{array}$ & $\begin{array}{c}\text { Rooting } \\
(\%)\end{array}$ \\
\hline Sand & $92 \mathrm{a}^{\mathrm{z}}$ & $28 \mathrm{bc}$ \\
Peat & $61 \mathrm{c}$ & $26 \mathrm{bc}$ \\
$\begin{array}{l}\text { Perlite } \\
\text { Peat and } \\
\text { perlite 1:1 }\end{array}$ & $70 \mathrm{bc}$ & $47 \mathrm{a}$ \\
$\begin{array}{l}\text { Vermiculite } \\
\quad \text { coarse) }\end{array}$ & $67 \mathrm{c}$ & $53 \mathrm{a}$ \\
$\begin{array}{l}\text { Vermiculite } \\
\quad \text { fine })\end{array}$ & $62 \mathrm{c}$ & $33 \mathrm{bc}$ \\
\hline
\end{tabular}

${ }^{\mathrm{z}}$ Means are calculated from five replicates of 20 cuttings each. Values in the same column followed by different letters are significantly different $(P<0.05)$ according to Wald test. among vermiculite (coarse), peat, sand, and vermiculite (fine).

Cutting orientation. Cuttings placed vertically gave the highest percentage of callusing, whereas those placed at $45^{\circ}$ gave the lowest in both years (Table 6 ). The percentage of callusing on inverted cuttings was significantly lower than that on vertical cuttings. Inverted cuttings showed a significantly higher percentage of callusing than those placed horizontally.

Cuttings placed vertically gave the highest rooting percentage in both years (Table 6) with no significant difference in percentage rooting between vertical and angled cuttings in Year 1 but a significantly lower level in Year 2. Cuttings placed horizontally, or inverted, gave practically no rooting (one inverted was rooted).

\section{Discussion}

As a relatively new cherry rootstock, 'Gisela 5' has not yet been subjected to extensive scientific study, resulting in limited knowledge of its vegetative propagation from hardwood cuttings. Vegetative propagation is gaining in importance as the economical life of cherry orchards is becoming shortened as a result of innovations in planting layout and selection of new cultivars with better fruit quality. Consequently, increasing quantities of planting material are required.

In comparison with other types of cuttings (semihardwood, softwood, and so on), hardwood cuttings are
Table 6. The effect of cutting orientation on percentage callusing (cuttings with callus + cuttings also with roots) and rooting of hardwood cuttings of the 'Gisela 5' cherry rootstock $[20 \mathrm{~cm}$ (7.9 inches) long and 9 to $11 \mathrm{~mm}(0.35$ to 0.43 inch) in diameter].

\begin{tabular}{lccr}
\hline \multirow{2}{*}{$\begin{array}{lcc}\text { Cutting } \\
\text { orientation }^{\mathrm{z}}\end{array}$} & \multicolumn{3}{c}{ Callusing (\%) } \\
\cline { 2 - 4 } Year 1 & Year 2 & Mean \\
\hline Vertical & $82 \mathrm{a}^{\mathrm{y}}$ & $77 \mathrm{a}$ & $80 \mathrm{a}$ \\
Angle & $44 \mathrm{~d}$ & $42 \mathrm{~d}$ & $43 \mathrm{~d}$ \\
Inverted & $65 \mathrm{~b}$ & $72 \mathrm{~b}$ & $69 \mathrm{~b}$ \\
Horizontal & $56 \mathrm{c}$ & $53 \mathrm{c}$ & $55 \mathrm{c}$ \\
\hline Cutting $^{4}$ Rooting (\%) \\
\cline { 2 - 4 } orientation $^{\mathrm{z}}$ & Year 1 & Year 2 & Mean \\
Vertical $_{\text {Angle }}$ & $16 \mathrm{a}$ & $24 \mathrm{a}$ & $20 \mathrm{a}$ \\
Inverted $_{\text {Horizontal }}^{11 \mathrm{a}}$ & $9 \mathrm{~b}$ & $10 \mathrm{~b}$ \\
Ho b & $1 \mathrm{c}$ & $1 \mathrm{c}$ \\
\hline
\end{tabular}

${ }^{z}$ Orientation of cuttings by which they were placed in bottom heat. The cuttings were set vertically in the conventional orientation, horizontally, inverted and at $45^{\circ}$.

${ }^{y}$ Means are calculated from five replicates of 20 cuttings each. Values in the same column followed by different letters are significantly $(P<0.05)$ according to Wald test.

easy to take, handle, and store, which allows for flexibility in the preparation of the cutting and, in general, less precision than cuttings that include actively growing tissue (Hartmann et al., 2002). There is less chance of cutting desiccation or mechanical damage during all stages of handling, storage, preparation, and placement in the greenhouse. Hardwood cuttings are taken at a time of year when field responsibilities are limited and there is little need for special treatment, other than cold storage, before the cuttings are dealt with in the greenhouse. Helpfully, more dormant deciduous cuttings than summer cuttings can be stored per unit area because of the absence of foliage (Hartmann et al., 2002). Hartmann et al. (2002) also reported that the juvenility of cuttings plays an important role in rooting and factors such as cutting length and diameter, collection date, and position of cuttings on the parent shoots affect the rooting of hardwood cuttings.

The present study also indicated that the second half of November and the first days of March are better for collecting cuttings than early December, in line with earlier studies that indicated November as the best month to collect hardwood cuttings 
for propagation of peach (Gill and Chitkara, 1990; Tsipouridis et al., 2005 ). This 'Gisela 5' study suggests that $20-\mathrm{cm}$ long cuttings with 9 to 11 $\mathrm{mm}$ diameter collected from the middle of the parent shoots and treated with $1 \mathrm{~g} \cdot \mathrm{L}^{-1}$ IBA gave the best rooting. Abdullah et al. (1988) reported that the best rooting of hardwood cuttings of american sycamore (Platanus occidentalis) was obtained with $25-\mathrm{cm}$ long cuttings cut $1 \mathrm{~m}$ from the shoot base of the 8-year-old tree. Hardwood cuttings taken from more basal or middle cane segments of the 'Norton' grapevine rootstock (Vitis aestivalis) rooted better than cuttings from the apical region (Keeley et al., 2004) and Marini (1983) found that cuttings of peach $5 \mathrm{~mm}$ in diameter rooted $100 \%$ better than those of $2 \mathrm{~mm}$.

Synthetic auxins such as IBA have a strong promotional action on rooting of cuttings, other than hardwood, of the 'Gisela 5' cherry rootstock (Stefancic et al., 2006; Wang et al., 2005). The optimal IBA concentration for rooting hardwood cuttings varies between species (Ozkan et al., 2005; Pirlak, 2000; Rosier et al., 2004; Tsipouridis et al., 2004, 2005 ) and in this study, $\mathrm{l} \mathrm{g} \cdot \mathrm{L}^{-1}$ produced the best results.

The characteristics of rooting substrates are very important for rooting success (Pokorny and Austin, 1982). A good rooting substrate will have a high waterholding capacity combined with a high degree of aeration. Verdonck et al. (1983) have attempted to quantify these requirements for optimal rooting and suggest that $20 \%$ of the volume of an ideal rooting substrate should be air space and $20 \%$ to $30 \%$ readily available for water. The results of this study indicated that perlite:peat (total porosity $70 \%$, waterholding capacity $30 \%$ ) and perlite (total porosity $75 \%$, waterholding capacity $20 \%$ ) are optimal for 'Gisela 5' hardwood cuttings. Tofanelli et al. (2003) tested six rooting substrates (sand, carbonized rice husk, vermiculite, sand + carbonized rice husk, sand + vermiculite, and carbonized rice husk + vermiculite) for rooting of peach hardwood cuttings and found that the highest rooting frequency was obtained with vermiculite, independent of thickness. Denny and Arnold (2001) found the perlite substrate the best for the rooting of cuttings of american smoketree (Cotinus obovatus), whereas Ercisli et al. (2002) found the highest rooting percentage for kiwifruit (Actinidia chinensis) hardwood cuttings was obtained in peat + perlite and peat + sawdust substrates. Tsipouridis et al. (2005) found that perlite was the best rooting substrate for peach hardwood cuttings.

Sinnott (1960) states that polarity is the first step in differentiation and this is inherent in the tissues themselves and not dependent on gravity. Rooting of cuttings involves such a gradient of growth regulator within the stem, and it is a consequence of the polarity of the tissues and not the cause of this (Wareing and Phillips, 1975). The results of this study showed that vertically placed hardwood cuttings gave the highest rooting percentage with similar results reported by Tsipouridis et al. (2005). Polarity reversal can result in a drastic decrease $(60 \%)$ in rooting percentage of hardwood cuttings of 'Kober 5BB' grapevine rootstock (Vitis berlandieri $\times$ Vitis riparia) (Cristoferi et al., 1988). One inverted cutting did produce roots during this investigation, but no further information was collected from it.

Some bacteria such as those belonging to the genus Agrobacterium can release auxin and affect positively the rooting of cuttings (Sezai et al., 2003a, 2003b), but the results of this study showed no effect, or a negative effect, of $A$. rubi on callusing and rooting of cuttings. The relatively low percentage of rooting in the control cuttings for this part of the investigation was probably related to the diameter of cuttings used as it was shown in Expt. I with the cuttings 12 to $14 \mathrm{~mm}$ in diameter. In previous research, $A$. rubi and $A$. rhizogenes have been shown to promote the rooting of cuttings in different plants (Chen et al., 2004; Felker et al., 2005; Li and Leung, 2003; Sezai et al., 2003a, 2003b). Ercisli et al. (2004) reported three strains of A. rubi (Al, Al6, Al8) to stimulate adventitious root formation on hardwood stem cuttings of two rose (Rosa sp.) genotypes. It would appear that the strains of $A$. rubi used in this study were ineffective in improving the rooting of cuttings probably because of reduced quantities of auxin produced by these strains, but further work is needed to investigate the effectiveness of the infection process.

The study has shown improved rooting can be achieved for 'Gisela 5' using cuttings of 9 to $11 \mathrm{~mm}$ diameter and $20 \mathrm{~cm}$ length quick-dipped in $1000 \mathrm{mg} \cdot \mathrm{L}^{-1}$ IBA solution. In addition, the cuttings should be collected at 15 Nov. or 2 Mar. instead of the first days of December and placed vertically into a perlite:peat $(1: 1)$ or perlite rooting substrate. In practical terms, it appears this hardwood rootstock can be propagated by cuttings with a rooting percentage of $\approx 50 \%$.

\section{Literature cited}

Abdullah, Y.S., M.O. Abdullah, and J. Ashoo. 1988. Effect of tree age, cutting length and their distance from the base of shoots on the propagation of Platanus occidentalis L. seedlings. Mesopotamia J. Agr. 20:131-144.

Bassi, G. 2005. Influence of rootstocks on cherry production. Informatore Agrario 61:55-59.

Chen, K., S. Kuo, and C. Ho. 2004. Growth performance and taxane content of Taxus mairei cuttings with roots induced by Agrobacterium rhizogenes. Taiwan J. For. Sci. 19:133-142.

Cristoferi, G., N. Filiti, and F. Rossi. 1988. The effects of reversed polarity and acropetal centrifugation on the rooting of hardwood cuttings of grapevine rootstock Kober 5BB. Acta Hort. 227: 150-154.

Denny, C. and A. Arnold. 2001. Interactions among rooting substrate, phenological stage of cuttings and auxin concentration on the rooting of Cotinus obovatus. J. Appl. Hort. Lucknow 1:1316.

Ercisli, S., O. Anapali, A. Esitken, and U. Sahin. 2002. The effects of IBA, rooting media and cutting collection time on rooting of kiwifruit. Gartenbauwissenschaft 67:34-38.

Ercisli, S., A. Esitken, and F. Sahin. 2004. Exogenous IBA and inoculation with Agrobacterium rubi stimulate adventitious root formation on hardwood stem cuttings of two rose genotypes. HortScience 39:533-534.

Felker, P., D. Medina, C. Soulier, G. Velicce, M. Velarde, and C. Gonzalez. 2005. A survey of environmental and biological factors (Azospirillum spp., Agrobacterium rhizogenes, Pseudomonas aurantiaca) for their influence in rooting cuttings of Prosopis alba clones. J. Arid Environ. 61:227-247. 
Gill, D.S. and S.D. Chitkara. 1990. Propagation of peach and plum by semi-hardwood cuttings. Res. Dev. Rptr. 7:154-158.

Hartmann, H.T., D.E. Kester, F.T. Davies, and R.L. Geneve. 2002. Hartmann and Kesters' plant propagation: Principles and practices. 7th Ed. Prentice Hall, Upper Saddle River, NJ.

Keeley, K., J.E. Preece, B.H. Taylor, and I.E. Dami. 2004. Effects of high auxin concentrations, cold storage, and cane position on improved rooting of Vitis aestivalis Michx. Norton cuttings. Amer. J. Enol. Viticult. 55:265-268.

Li, M.S. and D.W.M. Leung. 2003. Root induction in radiata pine using Agrobacterium rhizogenes. Electron. J. Biotechnol. 6:254-270.

Liu, Q., L. Zhang, B. Li, and H. Zhao. 2005. A new cherry dwarf rootstock variety 'Gisela 5'. Acta Hort. Sinica 32:760.

Loach, K. 1988. Hormone applications and adventitious root formation in cuttings-A critical review. Acta Hort. 227: 126-133.

Lugli, S., R. Correale, A. Gaiani, M. Grandi, E. Muzzi, M. Quartieri, and S. Sansavini. 2005. New cherry rootstocks for intensive plantations. Rivista di Frutticoltura e di Ortofloricoltura 67:41-47.

Marini, R.D. 1983. Rooting of semihardwood peach cuttings as affected by shoot position and thickness. HortScience 18:718-719.

Ozkan, Y., A. Arslan, R. Gercekcioglu, and M. Gunes. 2005. Effect of indole butyric acid concentrations on rooting of the green and hard-wood cuttings of some plum clone rootstocks. Asian J. Chem. 17:310-318.

Pirlak, L. 2000. Effects of different cutting times and IBA doses on the rooting rate of hardwood cuttings of cornelian cherry (Cornus mas L.). Anadolu 10:122-134.
Pokorny, F.A. and M.E. Austin. 1982 Propagation of blueberry by softwood terminal cuttings in pine bark and peat media. HortScience 17:640-642.

Rosier, C.L., J. Frampton, B. Goldfarb, F.C. Wise, and F.A. Blazich. 2004. Growth stage, auxin type, and concentration influence rooting virginia pine stem cuttings. HortScience 39:1392-1396.

Sezai, E., E. Ahmet, C. Rustem, and S. Fikrettin. 2003a. Adventitious root formation of kiwifruit in relation to sampling date, IBA and Agrobacterium rubi inoculation. Plant Growth Regulat. 41:133-137.

Sezai, E., E. Ahmet, C. Rustem, and S. Fikrettin. 2003b. Effect of indole-3-butyric acid and different strains of Agrobacterium rubi on adventive root formation from softwood and semi-hardwood wild sour cherry cuttings. Turkish J. Agr. For. $27: 37-42$.

Sinnott, E.W. 1960. Plant morphogenesis. Amer. J. Bot. 39:69-78.

Sitarek, M., Z.S. Grzyb, and B. Omiecinaska. 2005. Performance of sweet cherry trees on 'Gisela 5' rootstock. Acta Hort. 667:389-391.

Stefancic, M., F. Stampar, and G. Osterc. 2006. Influence of IAA and IBA on root development and quality of Prunus 'Gisela 5' leafy cuttings. HortScience 40: 2052-2055.

Tofanelli, M., J. Rodrigues, and E. Ono. 2003. Rooting of peach cv. 'Okinawa' hardwood cuttings at different stem diameters, substrates, and pots. Ciencia Rural 33:437-442.

Trobec, M., G. Osterc, and F. Stefancic. 2004. Propagation of rootstocks 'M9' and 'Gisela 5' using a fog system method for greenwood cuttings. Zbornik referatov 1. Slovenskega sadjarskega kongresa z mednarodno udelezbo. Krško, Slovenia 2:601-609.
Tsipouridis, C.G., A. Isaakidis, A. Manganaris, I. Therios, and Z. Michailidis. 2004. Propagation and field performance of own-rooted peach trees. Aust. J. Exp. Agr. 44:1225-1229.

Tsipouridis, C., T. Thomidis, and Z. Michailides. 2005. Influence of some external factors on the rooting of GF677 peach and nectarine shoot hardwood cuttings. Aust. J. Exp. Agr. 45:107-113.

Verdonck, O., R. Penninck, and M. De Boodt. 1983. The physical properties of different horticultural substrates. Acta Hort. 150:155-160.

Walter, E. and B.S. Franken. 1998. Evaluation of new German rootstocks for sweet cherry. 'Gisela 5' and other hybrids of $P$. cerasus $\times P$. canescens [Prunus avium L. ]. Rivista di Frutticoltura e di Ortofloricoltura 60:24-28.

Wang, G., H. Wu, D. Su, and J. Na. 2005. Effects of NAA and IBA on biochemical metabolism and rooting of cherry (Prunus psendocerasus Colt) cuttings. Acta Hort. Sinica 32:691-694.

Wareing, P. and I. Phillips. 1975. The control of growth and differentiation in plants. Pergamon Press, Oxford/New York.

Whiting, M.D. and D. Ophardt. 2005. Comparing novel sweet cherry crop load management strategies. HortScience 40: 1271-1275.

Yang, X., L. Zhang, B. Li, and Q. Liu. 2005. Brief report on the sweet cherry cultivars and rootstocks grown in Germany. China Fruits 4:61-62.

Zimmermann, A. 1994. 'Gisela 5', a dwarfing rootstock for sweet cherries from Giessen in a trial. Obstbau (Germany) 19:62-63. 